\title{
Customers repurchase intention formation in e-commerce
}

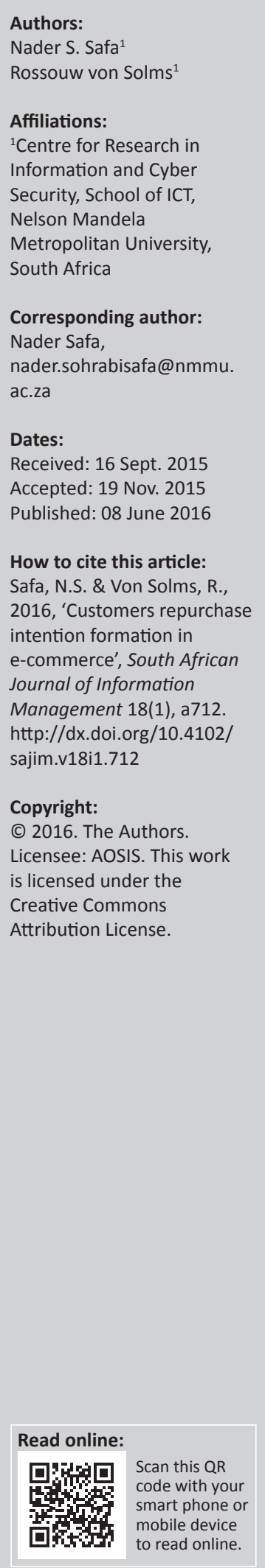

Background: Electronic loyalty (e-loyalty) has become important in the context of electronic commerce (e-commerce) in recent years. Loyal customers bring long-term revenue to companies and are known to be a valuable asset to them. However, firms lose their customers in a competitive environment on the Internet because of a lack of trust, satisfaction and loyalty.

Objectives: This study explains how e-loyalty, e-trust and e-satisfaction form in e-commerce with a focus on customer purchase intention formation.

Method: A conceptual framework was formed based upon the literature review. Data were collected from e-customers of online firms in South Africa. After data clarification, confirmatory factor analysis was conducted. The structural equation modelling was applied to test the hypotheses. IBM SPSS AMOS 20 was used for this purpose.

Results: Firstly, convenience, customer benefit and enjoyment affect customer satisfaction in e-commerce. In other words, when customers do business activities easily with enjoyment and take benefit, they are satisfied and they will purchase again in future. Secondly, our study demonstrated that customer perception of security, clear shopping process and reliable payment system have a positive relationship with e-trust. Finally, e-satisfaction and e-trust have a positive and strong relationship with e-loyalty formation in e-commerce.

Conclusion: The results of the study shed light on important issues relating to e-loyalty formation from a new perspective. Online companies are interested in launching e-loyalty programmes because of the long-term benefits that come from loyal customers. To remain competitive, e-commerce companies should constantly work at enhancing customer trust, satisfaction and loyalty.

\section{Introduction}

e-Loyalty has been an key issue in the research of e-commerce in recent years because of its benefits for business. e-Loyalty leads to repurchasing and is defined as a customer's commitment and favourable attitude towards online companies (Safa 2014). Loyalty in e-commerce refers to the individual's intention to make another purchase from the same firm, based on their previous commerce activities. Therefore, the identification of effective factors on e-loyalty is important for both the researcher and practitioners (Tsai \& Huang 2007). However, according to Wang, Pallister and Foxall (2006) previous research on e-loyalty has been largely fragmented, and the studies on the e-loyalty formation structure are few. Loyal customers bring long-term benefits for firms and are acknowledged to be a valuable asset for them. Loyal customers invite new customers to purchase from their favourite company and are a rich resource for profit (Chen 2012). e-Loyalty reduces the operating costs because loyal customers buy more than other customers. Although e-loyalty formation costs are more than loyalty creation in traditional commerce, the benefits and growth accelerate faster once the relationship has been built (Cyr et al. 2007). The results of previous research point to the importance of e-loyalty development in e-commerce. In describing e-loyalty formation, e-trust and e-satisfaction play a vital role (Chang \& Chen 2008). Different studies discuss the sequence effect of e-trust and e-satisfaction. Mazaheri, Richard and Laroche (2011) investigated the effect of site atmospherics in terms of pleasure and entertainment. Site involvement, site attitude and purchase intention between Chinese and Canadian customers were the focus of their study. This research endeavours to show that once customers enjoy, benefit and convenience, and are conversant with online purchasing, they are satisfied and that when there is security, a clear shopping process, reliable payment system and benevolence, they trust the online companies. Finally, e-trust and e-satisfaction lead to repurchasing and the formation of e-loyalty. 


\section{Theoretical background}

Cognition affects people's reaction in daily activities. Cognition, affect and behaviour show the formation of human behaviour. Cognition refers to an individual's belief, perception and thought about an object when he or she interacts with the object (Park, Campbell \& Kwak 2012). Affect refers to favourable disposition towards a stimulus that leads to a relative preference. In this research, feeling of convenience, benefit and enjoyment affect customers' satisfaction on one hand, and sense of security, clear shopping process, reliable payment system and benevolence influence customers' trust. Finally, perception of satisfaction and trust lead to actual behaviour (loyalty) in customers (Safa \& Ismail 2013). A review of the literature revealed that e-satisfaction and e-trust play vital roles in the formation of e-loyalty. Based on this view, the research model development was presented in two parts:

1. The previous studies that relate to the formation of e-satisfaction.

2. The former investigations that relate to the formation of e-trust.

\section{Research model and hypotheses development}

Retaining loyal customers is a key to e-commerce success. Previous studies have shown that there is a relationship between the profitability and growth of companies and customer purchasing with loyalty (Chen, Shang \& Kao 2009). This study, in line with the previous studies, considers customer repurchasing, which refers to loyalty as a main construct for the success of e-commerce. In the different studies, e-trust and e-satisfaction have frequently been mentioned as two main factors that influence e-loyalty (Chang et al. 2008; Gefen \& Straub 2004; Shankar, Smith \& Rangaswamy 2003). Convenience (Lin, Wu \& Chang 2011), customer enjoyment (Kim et al. 2012) and customer benefits (Bosnjak, Galesic \& Tuten 2007) are the factors that influence e-satisfaction and security (Kim et al. 2010), whilst clear shopping process (Kim et al. 2010), reliable payment system (Kousaridas, Parissis \& Apostolopoulos 2008) and benevolence (Gefen et al. 2004) are the constructs that influence e-trust.

\section{e-Satisfaction}

Customer satisfaction has attracted considerable attention from academic and e-commerce companies in recent years. Satisfied customers are more likely to repurchase from a company that has satisfied them from their previous shopping through the Internet (Shankar et al. 2003). In most research in this domain, satisfaction is the main factor in the formation of loyalty. Satisfied customers will purchase again and bring long-term benefits for companies (Auh \& Johnson 2005; Tsai et al. 2007). Retaining and increasing loyal customers are very important for e-commerce companies, and having an effective plan for increasing customer satisfaction is necessary for surviving in the competitive environment of the Internet. Different experts have discussed e-satisfaction from various perspectives. Følstad, Anda and Sjøberg (2010) investigated customer satisfaction in terms of general and specific context. The results of their investigation revealed that perceived ease of use and usefulness affect customer satisfaction and satisfaction influences loyalty in e-commerce. Bridges and Florsheim (2008) considered perceived enjoyment as the main factor that influences customer connectivity and satisfaction with the e-commerce system. Hedonism (sense of pleasure) has also been considered as a factor that influences e-satisfaction and e-loyalty (Bridges \& Florsheim 2008; Overby \& Lee 2006; Van Schaik \& Ling 2008). System and information quality and customer perception (ease of use and usefulness) are the factors that have frequently been mentioned by scholars that lead to customer satisfaction (Lin et al. 2011; Stefani \& Xenos 2011). In the different research, satisfaction has been studied in two perspectives. On the one hand, satisfaction is an affective predisposition sustained by economic condition, such as the volume of profit margins or sales obtained. On the other hand, nonpsychological factors such as the ease of relationships or partner fulfilling promises are considered as non-economic satisfaction. Satisfaction with economic and non-economic aspects influences customer loyalty in the e-commerce (Casaló, Flavián \& Guinalíu 2008).

\section{Customer enjoyment}

Customer enjoyment refers to the enjoyable connectivity to the computer system. Perceived enjoyment also refers to cognitive information processing and influences customer satisfaction (Dubé, Cervellon \& Jingyuan 2003). Online customer behaviour has focused on hedonism in recent years and discussed the fun and benevolent aspects of using e-commerce on the Internet. Hedonic in e-commerce refers to the feeling of pleasure in purchasing. Kim et al. (2012) investigated the effect of hedonic value on customer satisfaction based on the gender and income of the customers. Bridges and Florsheim (2008) investigated the effect of convenience, safe and pleasant shopping on e-satisfaction. An enjoyable experience of shopping leads to more online buying and e-loyalty in e-commerce. The results show that an enjoyable shopping experience and considering customer benefits increase customer satisfaction in Internet shopping. Van Schaik and Ling (2008) examined the effect of screen design, information organization and Internet experience on customer enjoyment and satisfaction. The outcome of their research revealed that site beauty influences customer enjoyment and leads to repurchasing. Communication theory discusses the information process and human communication. Based upon this theory, transmission and quality of information influence customers (Kim et al. 2005). In another study, Hwang (2010) investigated the moderating effect of gender on e-commerce system adoption. The results showed that the effect of enjoyment as an intrinsic motivation in 
women is stronger than that in men. In literature, customer enjoyment has been considered as a factor that influences e-satisfaction in this framework.

\section{Customer benefit}

Customers can purchase in the minimum of time and avoid traffic and other vulnerabilities, such as robbery or accident. Less cost, time, error and mistakes are the advantages of e-commerce. The good qualities of the products as well as the perceived fairness of price are the important factors that influence customer decisions to purchase online. Customers compare the price of products and services and based on their benefit make a decision (Bosnjak et al. 2007). Min and Wolfinbarger (2005) examined the effect of profit margin and marketing efficiency in e-commerce. The results of their research showed that lower price and customer benefit play an important role in customer satisfaction and repurchasing. Previous studies revealed that once online companies consider reward and discount for their e-customers, they are more satisfied with their online shopping (Quaddus \& Achjari 2005). According to the Exchange Theory, human relationships form based on the comparison of alternatives and subjective cost-benefit analysis. This theory has its roots in sociology, economics and psychology. Maximizing benefit and minimising cost are two important factors in human decision-making and their relationship. Therefore, people consider the benefit and risk in their activities. When risk increases, they abandon or terminate their relationship (Kim et al. 2005). In this research, customer benefits are amongst the factors that influence customer satisfaction and lead to repurchasing and loyalty in e-commerce.

\section{Convenience}

Convenience is defined as the extent to which customers feel that the website is user friendly, simple and intuitive. Accessibility of information and easiness of the transaction process have a significant effect on customer satisfaction (Chen, Hsu \& Lin 2010). According to Salehi, et al. (2012), customers leave e-commerce websites without any activity or purchase when they cannot find their way through the system. Hernandez investigated the moderating effect of the e-purchasing experience in e-commerce. Their research group focus comprised two groups of customers: (1) experienced e-customers and (2) customers who had low experience in e-commerce. The perceptions that induce customers to purchase through the Internet for the first time are not the same as those that produce repurchasing behaviour. More e-commerce experience leads to convenience and satisfaction in e-commerce (Hernández, Jiménez \& Martín 2010). The search facility in the e-commerce system enables customers to obtain the information that they need, and providing accessible information and visibility are important factors for e-customer convenience (Lin et al. 2011). Short response time and fast completion of transactions with minimum customer effort lead to convenience in e-commerce. The theory of minimum effort, which discusses human satisfaction with minimum effort to reach a goal, supports the factor of convenience in the study. In addition, the perceived ease of use in the technology acceptance model also confirms the convenience of customers in e-commerce and has been mentioned frequently by experts (Qiu \& Li 2008). Customers expect a fast and efficient process in their e-commerce activity. They will not come back for purchasing if customers become frustrated in e-commerce.

\section{e-Trust}

In any commercial activity, trust plays a vital role and is a collective and institutional attribute that is drawn upon to achieve particular goals. Trust also encourages partners to cooperate in transactions (Safa \& Ismail 2013). The transactions are between two individuals, firms or individuals and firms. Different experts have discussed trust in different perspectives, such as technological, organizational and managerial, behavioural and psychological, economic and game theoretic approaches (Kirs \& Bagchi 2012). Berry discussed trust as a very powerful tool in marketing. Needless to say, trust plays a vital role in e-commerce like any commercial exchange involving monetary transactions (Koh \& Sundar 2010). In contrast with traditional commerce, trust in e-commerce is based on the customer confidence in the process. Trust is identified as the key factor in the success of e-commerce and its influence on customer loyalty. IglesiasPradas et al. (2013) investigated the barriers of e-shopping with focus on non-shopper behaviour. The results of their research revealed that trust and security issues are the most significant barriers to keep deterring customers from shopping on the Internet. Beldad, de Jong and Steehouder (2010) discussed different determinants of online trust formation in commercial and non-commercial online transaction. The outcomes of their study showed that trust plays a vital role when firms rely on the Internet for delivery of their products or services. The lack of trust could thwart users from engaging in online transactions with the companies.

\section{Security}

It is commonly believed that the perception of security improves customer trust and that trust leads to repurchasing by customers and brings enormous benefits for companies (Safa et al. 2015). e-Commerce systems save customer information and also the information concerning their transactions during Internet shopping. Customer information can be analysed for a variety of purposes, which increases the risk for customers. That is why customers consider the security of the system as an important factor in e-commerce. The concept of perceived security is the greatest challenge for customers who want to buy products or services on the Internet. Authentication, verification, protection and encryption, as suggested by Kim et al. (2010), influence the customer security perception. Customers know that their information is collected, recorded and may be used later for undesirable purposes, which is always a concern. Therefore, perceived security is a subjective probability for customers in e-commerce that their financial and personal information 
will not be shown, saved or stolen in the e-commerce activity.

\section{Reliable payment system}

e-Commerce is built based on the Electronic Payment System (EPS), which is one of the important issues in the success of e-commerce (Kousaridas et al. 2008). Easy payment, privacy, reliability, security, acceptability, scalability and anonymity are the factors that influence EPS and are the different aspects in comparison with traditional payment methods (Carbonell, Sierra \& Lopez 2009; Safa, Ghani \& Ismail 2014). Transactions occur without any prior customer contact or interpersonal relationship in the e-commerce environment. Security threats in e-commerce from interpersonal networks or media cause people to think about security in EPS (Carbonell et al. 2009). Generally, security is a set of computer programmes, procedures and mechanisms for guaranteeing the process and authenticating the source of information (Kim et al. 2010). Although the extant literature extensively discusses EPS and trust in terms of service providers, merchants and customer perception, a safe payment system has not been adequately studied or addressed in this domain (Dai \& Grundy 2007). In this study, a reliable payment system is considered one of the main factors that lead to customer trust and loyalty.

\section{Clear shopping process}

Understanding the online shopping process to establish and sustain e-commerce is important for retailers and companies. Muylle and Basu (2004) examined the extent to which companies in different industries support online processes through their website. Their findings showed that a clear shopping process is important for the success of e-commerce. The shopping process encompasses information search, product awareness, product trial, transaction and distribution. Shopping activities fragment because of multiple stages. Shopping processes are divided into several sub-processes because they are performed at varying times, locations and stages of purchasing (Cao 2012). Kim and Forsythe (2008) discussed the effect of virtual try-on in online shopping to reduce product risk and increase enjoyment. They also examined the effect of technology anxiety and innovativeness on e-shopping. The results revealed that a simple, understandable and clear shopping process leads to customer trust in e-commerce. A clear shopping process helps customers to make a decision about purchasing in the Internet environment. Bechwati and Xia (2003) investigated the effect of customer perceptions about the shopping process and the effort required for e-purchasing on the decision of customers to perform e-commerce activities. The results of their study revealed that understanding the shopping process helps customers to make decisions and leads to trust and repurchasing. In this study, a clear shopping process is one of the main factors that influence customer trust in e-commerce.

\section{Benevolence}

Benevolence in e-commerce is defined as the positive perception of e-commerce and the orientation of the online company. Benevolence is the extent to which a trustee is believed to want to do good to the trustor, aside from an egocentric profit motive'. Gefen et al. (2004) discussed benevolence as well as the ability and integrity to develop trust. They defined integrity as the trustor's perception that 'the trustee adheres to a set of principles that the trustor finds acceptable'. Experts believe that it must be recognised that trust in e-commerce has aspects that are different from traditional commerce. Trust relates to the interpersonal determinants of behaviour, which deal with the beliefs about the integrity and benevolence, ability and predictability of the other people. Based on their request and interests, customers trust more once they feel that the online company can help them when they need help to choose proper products (Gummerus et al. 2004). In other words, the level that customers feel that the e-commerce site is targeted at them and the services fulfil their needs leads to customer trust (Lai 2006). In this research, benevolence has been considered as a factor that influences trust in e-commerce.

Table 1 shows the definition of effective factors in the model in a concise form.

The cognition-affect-behaviour model was applied to show e-loyalty formation in e-commerce (Figure 1). Customer beliefs, perceptions or thoughts form their cognition during their interaction with the shopping environment, products and services, which shows the effect of the interaction. Based on the model, customer perception of convenience, benefits

\begin{tabular}{|c|c|}
\hline Factor & Definition \\
\hline Enjoyment & Refers to the enjoyable connectivity to the e-commerce system and pleasant shopping. \\
\hline Benefits & $\begin{array}{l}\text { Refers to advantages of e-commerce such as spending less time and cost, avoiding traffic, robbery and accident, having reward and } \\
\text { discount and so on. }\end{array}$ \\
\hline Convenience & $\begin{array}{l}\text { Refers to the customers' feel about the e-commerce system in terms of accessibility of information and easiness of the transaction } \\
\text { process. }\end{array}$ \\
\hline Security & Refers to the security of the e-commerce system in terms of financial and personal information. \\
\hline Reliable Payment System & Reliability of the system in terms of financial transactions. \\
\hline Benevolence & The extent to which e-commerce company considers the benefit, interest and request of customers in their system. \\
\hline e-Satisfaction & Refers to perception of satisfying fulfilment over customer transaction experiences. \\
\hline e-Trust & Refers to the perception of confidence in the exchange reliability and integrity. \\
\hline e-Loyalty & Repeated buying behaviour in a particular period of time. \\
\hline
\end{tabular}




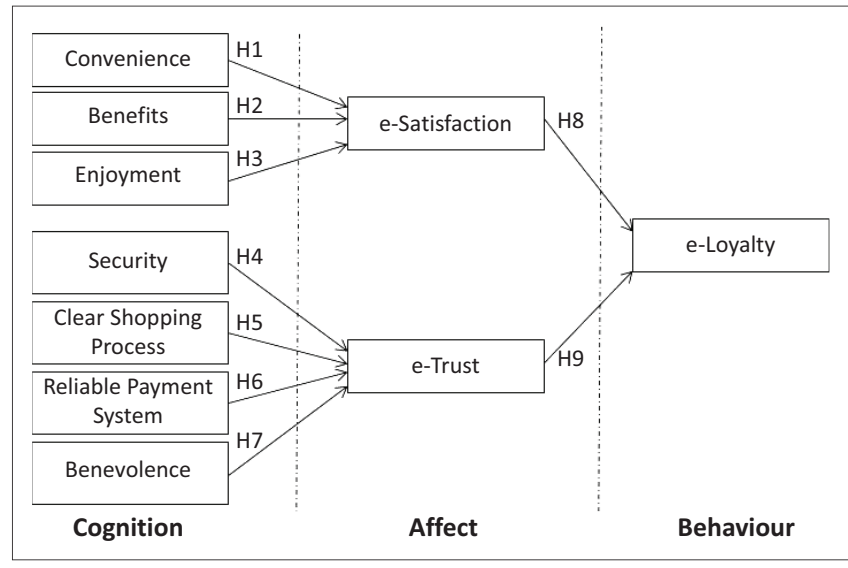

FIGURE 1: e-Loyalty formation model.

and enjoyment affect e-satisfaction on the one hand, and security, clear shopping process, reliable payment system and benevolence affect e-trust, on the other hand, in which the two together lead to e-loyalty behaviour (Chang \& Chen 2009). The following hypotheses have been considered for this research:

H1: Convenience has a positive effect on customer e-satisfaction.

H2: Customer benefits have a positive effect on customer e-satisfaction.

H3: Customer enjoyment has a positive effect on customer e-satisfaction.

H4: Security has a positive effect on customer e-trust.

H5: Clear shopping process has a positive effect on customer e-trust.

H6: Reliable payment system has a positive effect on customer e-trust.

H7: Benevolence has a positive effect on customer e-trust. H8: e-Satisfaction has a positive effect on customer e-loyalty.

H9: e-Trust has a positive effect on customer e-loyalty.

\section{Research methodology}

Every study starts to solve a problem or improve a system. Today, companies lose their customers in the competitive environment on the Internet. The lack of trust, satisfaction and loyalty are the main factors leading to the breakdown of e-commerce. As mentioned before, loyal customers are a valuable asset for companies. Therefore, retaining and increasing loyal customers is necessary. Based upon the literature review, a conceptual framework is formed. Data were collected from e-customers of online firms in South Africa. After data clarification, confirmatory factor analysis was conducted. The structural equation modelling was applied to test the hypotheses. IBM SPSS AMOS 20 was used for this purpose. More explanation will be presented in the next part.

\section{Data collection}

Our research subjects were the customers of online companies who had at least several Internet shopping experiences in South Africa from first of January to end of March. The participants were asked to fill out the questionnaires based on their experience with e-commerce. The questionnaires were also sent through the Internet to the email of some participants who we had their email address in order to speed up data collection. The number of respondents was 283, from which 18 questionnaires were discarded because of the same rating given to all questions or they were incomplete. Finally, 265 questionnaires were retained for analysis.

\section{Demography}

The relationship between Internet purchasing intention and customer demographic has been mentioned important by the other experts (Akhter 2003). The results of demographic analysis are presented in Table 2. Gender is relatively equal between (50.9\%) women and $(49.1 \%)$ men. The largest age group was 30-39 (54.55\%), followed by 20-29 (17.85\%), 40-49 $(26.67 \%)$ and above age $50(1.2 \%)$. The academic level of participants was relatively high. Most of the participants in the survey had three experiences of online purchasing per month. The samples show a diversity in terms of age, education and e-commerce experience with almost equal representation of gender.

\section{Measurements}

The questionnaire was applied to measure customer perception of the research framework, which was adopted from previous research. A Likert scale was used for measuring each item, from (1) strongly disagree to (5) strongly agree. First, a pilot study was carried out with 32 questionnaires and items revised before finalizing the main survey content. The preliminary version of the questionnaire was pilot-tested in order to investigate whether all the participants understood the questions in a similar way and

TABLE 2: Demography of participants.

\begin{tabular}{llll}
\hline Demography & Category & $f$ & $\%$ \\
\hline Gender & Male & 130 & 49.1 \\
Age (years) & Female & 135 & 50.9 \\
& $20-29$ & 46 & 17.58 \\
& $30-39$ & 144 & 54.55 \\
Occupation & $40-49$ & 70 & 26.67 \\
& $>50$ & 5 & 1.20 \\
Education & University students & 127 & 48.1 \\
& Company employees & 138 & 51.9 \\
Number of EC use & PhD & 53 & 19.4 \\
& Master's degree & 91 & 34.5 \\
& Bachelor's degree & 121 & 46.1 \\
& 2 & 42 & 15.8 \\
& 3 & 51 & 19.4 \\
& 4 & 59 & 22.4 \\
& 5 & 50 & 19.4 \\
& 6 & 38 & 14.5 \\
& 7 & 11 & 4.3 \\
& 8 & 6 & 1.8 \\
& $>9$ & 4 & 1.2 \\
& & 4 & 1.2 \\
\hline
\end{tabular}


whether they interpreted questions in the same manner. We described the purpose of this research for them and asked to answer the questionnaire in the presence of one of the authors and to provide feedback regarding wording, applicability and understandability of the instruments. Item identification analysis was applied to evaluate the results of the pilot study that combined the identification of the index score with descriptive statistics. The measures of the homogeneity test were less than 2 (Chang \& Chen 2009). Finally, 39 measurement items remained for the main construct.

\section{Data analysis}

\section{Analysis of the measurement model}

Confirmatory factor analysis was applied for developing the measurement model. Structural equation modelling was established for hypothesis testing. The maximum likelihood method in IBM SPSS AMOS 20 was used for assessment of the model. Chi-square with degrees of freedom, goodness of fit index (GFI), adjusted goodness of fit index (AGFI), normed fit index (NFI), comparative fit index (CFI) and root mean square error of approximation (RMSEA) were employed to evaluate the model. In this model NFI, GFI, AGFI and CFI were all greater than 0.9, and RMSEA was less than 0.08; therefore, we have a fit model. The measure of chi-square is 665.528 with 226 degrees of freedom $(665.528 / 226<3, p=0.000)$, indicating a good fit model (Hair et al. 2010).

Every construct was evaluated separately by construct validity, indicator loading, discriminant validity and convergent validity. The loading of the items for all constructs was significant. The average variance extracted and composite reliability were applied for reliability assessment. The composite reliabilities were between 0.72 and 0.85 (more than 0.7 ) and the AVEs between 0.56 and 0.71 (more than 0.5). In addition, the item loadings were between 0.62 and 0.91 , which were above the recommended cut-off level of 0.6. Therefore, the convergent validity is acceptable (Chang et al. 2009). Table 3 shows the measures of the model in first order and after consideration to improve it. In the second order, the items with loading less than 0.6, which lead to low convergent validity, and the items with high error were omitted from the model (Chien, Chen \& Hsu 2012).

Table 4 shows the measures of factor loading, $t$-value, composite reliability and average variance extracted for the model.

\section{Testing the structural model}

Based on the recommended values, all fit indices show a good model fit $\left(\chi^{2} /\right.$ d.f. $=2.73, \mathrm{NFI}=0.92, \mathrm{GFI}=0.93, \mathrm{AGFI}=$ 0.91, CFI $=0.95$, RMSEA $=0.71$ ). Table 5 shows the standardized path coefficients in the model. H1 shows that convenience has a positive effect on e-satisfaction $\left(\gamma_{1}=0.45\right.$, $p<0.001)$. The outcomes also show that customer benefit $\left(\gamma_{2}=0.72, p<0.001\right)$ and customer enjoyment $\left(\gamma_{3}=0.61\right.$, $p<0.001)$ have a positive effect on e-satisfaction. In the trust section of the model, security $\left(\gamma_{4}=0.53, p<0.001\right)$, clear shopping process $\left(\gamma_{5}=0.61, p<0.001\right)$ and reliable payment system $\left(\gamma_{6}=0.58, p<0.001\right)$ have a positive effect on e-trust. Unexpectedly, the standard path coefficient was not significant for benevolence $(p>0.5)$. Thus, H7 was not supported. $\mathrm{H} 8$ and $\mathrm{H} 9$ proposed that the satisfaction and trust positively affect customer loyalty $\left(\gamma_{8}=0.79, p<0.001\right.$, $\left.\gamma_{9}=0.74, p<0.001\right)$.

\section{Implications}

The formation of loyalty in the Internet environment is not easily achieved and needs to be considered by firms. This research presented a model for the creation of e-loyalty in e-commerce based on two main elements - e-trust and e-satisfaction. Firstly, convenience, customer benefit and enjoyment affect customer satisfaction in e-commerce. These findings are in line with previous research in this domain (Koo 2006; Salehi et al. 2012). These findings are also in line with the ease of use in the Technology Acceptance model and Exchange Theory, which discuss human relationships based on their benefit and cost. The results in this part implied that when customers do business activities easily with enjoyment and take benefit, they are satisfied and they will purchase again in future. Secondly, our study demonstrated that customer perception of security, clear shopping process and reliable payment system have a positive relationship with e-trust. These results are also in line with the results of other research that has been carried out previously (Keen et al. 2004; Zuccato 2007). However, benevolence had no significant direct effect on e-trust. Benevolence reflects the willingness to assist and support the customer and knowing what the customers expect from the seller on the Internet (Palvia 2009). The interviews with customers revealed that they do not have any sense about firms' benevolence because of the weak relationship between companies and their e-customers. Customer Relationship Management is necessary for the success of e-commerce. Indeed, Customer Relationship Management transfers the perception of willingness to assist, support, fulfil

TABLE 3: Comparison of measurement models of e-loyalty.

\begin{tabular}{|c|c|c|c|c|c|c|}
\hline Model & $\chi^{2} / d . f$. & NFI & GFI & AGFI & CFI & RMSEA \\
\hline First-order model & 3.65 & 0.79 & 0.85 & 0.87 & 0.74 & 0.18 \\
\hline Second-order model & 2.73 & 0.92 & 0.93 & 0.91 & 0.95 & 0.71 \\
\hline Recommended value & $<3$ & $>0.9$ & $>0.9$ & $>0.8$ & $>0.9$ & $<0.08$ \\
\hline
\end{tabular}

$\mathrm{NFI}$, normed fit index; GFI, goodness of fit index; AGFI, adjusted goodness of fit index, CFI, comparative fit index; RMSEA, root mean square error of approximation. 
TABLE 4: Summary of measurement scale.

\begin{tabular}{|c|c|c|c|c|c|}
\hline Constructs & Measured items & $\begin{array}{l}\text { Confirmatory } \\
\text { factor analysis }\end{array}$ & $t$-value & $\begin{array}{l}\text { Composite } \\
\text { reliability }\end{array}$ & $\begin{array}{c}\text { Average } \\
\text { variance } \\
\text { extracted }\end{array}$ \\
\hline \multicolumn{6}{|l|}{ Convenient } \\
\hline $\mathrm{CO} 1$ & Purchasing with minimum effort leads to my satisfaction. & 0.62 & 11.8 & 0.85 & 0.65 \\
\hline $\mathrm{CO} 2$ & I feel comfortable when I can buy any place and time. & 0.83 & 16.5 & - & - \\
\hline $\mathrm{CO} 3$ & A user-friendly and simple website lead to my satisfaction. & 0.91 & 19.3 & - & - \\
\hline $\mathrm{CO} 4$ & Easiness of transaction and accessibility of information satisfy me. & 0.71 & 17.4 & - & - \\
\hline \multicolumn{6}{|c|}{ Customer benefits } \\
\hline $\mathrm{CB} 1$ & Purchasing at a lower cost leads to my satisfaction in online shopping. & 0.76 & 13.3 & 0.75 & 0.58 \\
\hline $\mathrm{CB} 2$ & Purchasing with better quality leads to my satisfaction in online shopping. & 0.86 & 14.5 & - & - \\
\hline CB3 & $\begin{array}{l}\text { Purchasing with minimum time and avoiding traffic and robbery lead to my } \\
\text { satisfaction in online shopping. }\end{array}$ & 0.69 & 13.6 & - & - \\
\hline CB4 & Considering reward and discount in Internet purchasing lead to my satisfaction. & 0.73 & 12.9 & - & - \\
\hline \multicolumn{6}{|c|}{ Customer enjoyment } \\
\hline CE1 & I enjoy the organization of information, when I buy through the Internet. & 0.75 & 18.3 & 0.72 & 0.56 \\
\hline CE2 & Pleasant shopping satisfies me and I like to purchase again from such a site. & 0.65 & 17.9 & - & - \\
\hline CE3 & My experience on the Internet leads to enjoyment of the e-commerce activities. & 0.82 & 18.4 & - & - \\
\hline CE4 & When I buy from the website with high system quality, I enjoy the shopping. & 0.89 & 16.4 & - & - \\
\hline \multicolumn{6}{|l|}{ Security } \\
\hline SE1 & I trusted this website when I realized that their system is secure. & 0.82 & 16.3 & 0.84 & 0.67 \\
\hline SE2 & I trusted this website when I realized nobody accesses my information. & 0.91 & 16.1 & - & - \\
\hline SE3 & $\begin{array}{l}\text { I trusted this website when I realized nobody accesses my account and } \\
\text { transaction information. }\end{array}$ & 0.87 & 17.3 & - & - \\
\hline SE4 & I trusted this website when I realized the path of data transfer is secure. & 0.76 & 17.1 & - & - \\
\hline \multicolumn{6}{|c|}{ Clear shopping process } \\
\hline CSP1 & $\begin{array}{l}\text { When I understand the steps of shopping on the Internet, I can trust the online } \\
\text { company. }\end{array}$ & 0.73 & 16.7 & 0.79 & 0.71 \\
\hline CSP2 & $\begin{array}{l}\text { The tracking of the shopping process through the website leads to my trust in } \\
\text { e-commerce companies. }\end{array}$ & 0.86 & 15.9 & - & - \\
\hline $\mathrm{CSP} 3$ & A simple and fast ordering system leads to my trust in an e-commerce company. & 0.69 & 16.4 & - & - \\
\hline \multicolumn{6}{|c|}{ Reliable payment system } \\
\hline RPS1 & A reliable payment system leads to my trust in this website. & 0.79 & 17.8 & 0.81 & 0.63 \\
\hline RPS2 & I trust this website because I realize my bank account is safe. & 0.88 & 18.3 & - & - \\
\hline RPS3 & I trust this website because I am sure nobody can change my transaction data. & 0.91 & 18.1 & - & - \\
\hline RPS4 & I trust this website because I am sure the service provider is reliable. & 0.76 & 17.9 & - & - \\
\hline \multicolumn{6}{|l|}{ Benevolent } \\
\hline BE1 & I trust the system when their system helps me to make a decision in purchasing. & 0.82 & 15.9 & 0.85 & 0.67 \\
\hline BE2 & I trust them when their system provides products and services based on my need. & 0.92 & 16.7 & - & - \\
\hline BE3 & $\begin{array}{l}\text { I trust them when their system provides products and services based on my } \\
\text { requests. }\end{array}$ & 0.81 & 16.4 & - & - \\
\hline BE4 & I trust them when e-commerce company considers my rights. & 0.88 & 17.1 & - & - \\
\hline \multicolumn{6}{|c|}{ e-Satisfaction } \\
\hline ES1 & I am satisfied with my purchases from this website. & 0.82 & 15.6 & 0.78 & 0.73 \\
\hline ES2 & My decision to buy from this website was right. & 0.93 & 14.8 & - & - \\
\hline ES3 & I will buy my needs from this website in the future. & 0.72 & 15.2 & - & - \\
\hline ES4 & If I buy again, I would feel pleasure about my purchase. & 0.83 & 16.1 & - & - \\
\hline \multicolumn{6}{|l|}{ e-Trust } \\
\hline ET1 & I trust this website in terms of my privacy. & 0.76 & 16.4 & 0.76 & 0.69 \\
\hline ET2 & I am sure nobody will abuse my information in their system. & 0.91 & 16.9 & - & - \\
\hline ET3 & I trust this website for my bank account when I buy through this website. & 0.87 & 19.1 & - & - \\
\hline ET4 & This company has a secure path for data transfer. & 0.73 & 17.3 & - & - \\
\hline \multicolumn{6}{|l|}{ e-Loyalty } \\
\hline EL1 & I will try to buy from this website again and again. & 0.71 & 14.4 & 0.83 & 0.56 \\
\hline EL2 & This website is my first choice to buy through the website. & 0.85 & 15.6 & - & - \\
\hline EL3 & This website is my favourite retail website. & 0.77 & 16.1 & - & - \\
\hline EL4 & I recommend this site to my friends for purchasing. & 0.84 & 16.7 & - & - \\
\hline
\end{tabular}

$t$-value is significant at $p<0.05$.

customers' request and help the customers. It seems necessary that e-commerce companies pay attention to this weakness in the future. Finally, our research, in line with the other research, showed that e-satisfaction and e-trust have a positive and strong relationship with e-loyalty (Audrain-Pontevia, N'Goala \& Poncin 2013; Kim, Jin \&
Swinney 2009). This means that if customers trust an online company and they are satisfied with their purchase, they will buy again in the future. e-Trust and e-satisfaction are two important factors that lead to the formation of e-loyalty and loyal customers bring long-term benefit for companies in the Internet environment. 
TABLE 5: The results of structural equation model.

\begin{tabular}{|c|c|c|c|c|c|}
\hline Hypothesis & Hypothesized relationship & & Estimate & $t$-value & Conclusion \\
\hline $\mathrm{H} 1$ & Convenience & ---> e-Satisfaction & 0.45 & 6.44 & Supported \\
\hline $\mathrm{H} 2$ & Customer benefit & ---> e-Satisfaction & 0.72 & 9.35 & Supported \\
\hline H3 & Customer enjoyment & ---> e-Satisfaction & 0.61 & 7.65 & Supported \\
\hline $\mathrm{H} 4$ & Security & $--->$ e-Trust & 0.53 & 8.52 & Supported \\
\hline H5 & Clear shopping process & $--->$ e-Trust & 0.61 & 9.38 & Supported \\
\hline H6 & Reliable payment system & $--->$ e-Trust & 0.58 & 4.78 & Supported \\
\hline $\mathrm{H} 7$ & Benevolence & $--->$ e-Trust & 0.12 & 0.07 & Not Supported \\
\hline $\mathrm{H} 8$ & e-Satisfaction & ---> e-Loyalty & 0.79 & 8.67 & Supported \\
\hline H9 & e-Trust & $--->$ e-Loyalty & 0.74 & 8.53 & Supported \\
\hline
\end{tabular}

$t$-value is significant at $p<0.05$

\section{Conclusion}

The results of the study shed light on important issues relating to e-loyalty formation from a new perspective. In contrast to traditional commerce, satisfaction, trust and loyalty formation in e-commerce environment (faceless interaction) are a difficult challenge. Online companies are interested in launching e-loyalty programmes because of the long-term benefits that come from loyal customers. To remain competitive, e-commerce companies should constantly work at enhancing customer trust, satisfaction and loyalty.

The structure of this research is based on the cognitionaffect-behaviour model. The results revealed that when customers buy through the Internet conveniently with enjoyment, particularly when companies consider a reward and discount for them because of online purchasing, they benefit and are satisfied with their deals. In addition, security perception, besides clear shopping process and reliable payment system, positively affects their trust in the Internet environment. Trust on the one hand and satisfaction on the other hand play vital roles in the formation of the intention of customers to repurchase.

\section{Acknowledgements Competing interests}

The authors declare that they have no financial or personal relationships which may have inappropriately influenced them in writing this article.

\section{References}

Akhter, S.H., 2003, 'Digital divide and purchase intention: Why demographic psychology matters', Journal of Economic Psychology 24(3), 321-327. http://dx. psychology matters', Journal of Economic
doi.org/10.1016/S0167-4870(02)00171-X

Audrain-Pontevia, A.-F., N'Goala, G. \& Poncin, I., 2013, 'A good deal online: The impacts of acquisition and transaction value on E-satisfaction and E-loyalty' Journal of Retailing and Consumer Services 20 (2013) 445-452.

Auh, S. \& Johnson, M.D., 2005, 'Compatibility effects in evaluations of satisfaction and loyalty', Journal of Economic Psychology 26(1), 35-57. http://dx.doi.org/10.1016/j. joep.2003.10.002

Bechwati, N.N. \& Xia, L., 2003, 'Do computers sweat? The impact of perceived effort of online decision aids on consumers' satisfaction with the decision process' Journal of Consumer Psychology 13(1/2), 139-148. http://dx.doi.org/10.1207/ 153276603768344852

Beldad, A., de Jong, M. \& Steehouder, M., 2010, 'How shall I trust the faceless and the intangible? A literature review on the antecedents of online trust', Computers in Human Behavior 26(5), 857-869. http://dx.doi.org/10.1016/j.chb.2010.03.013

Bosnjak, M., Galesic, M. \& Tuten, T., 2007, 'Personality determinants of online shopping: Explaining online purchase intentions using a hierarchical approach', Journal of Business Research 60(6), 597-605. http://dx.doi.org/10.1016/j. jbusres.2006.06.008
Bridges, E. \& Florsheim, R., 2008, 'Hedonic and utilitarian shopping goals: The online experience', Journal of Business Research 61(4), 309-314. http://dx.doi.org/ 10.1016/j.jbusres.2007.06.017

Cao, X., 2012, 'The relationships between e-shopping and store shopping in the shopping process of search goods', Transportation Research Part A: Policy and Practice 46(7), 993-1002. http://dx.doi.org/10.1016/j.tra.2012.04.007

Carbonell, M., Sierra, J.M. \& Lopez, J., 2009, 'Secure multiparty payment with an intermediary entity', Computers \& Security 28(5), 289-300. http://dx.doi.org/ $10.1016 / j . \operatorname{cose} .2008 .12 .002$

Casaló, L., Flavián, C. \& Guinalíu, M., 2008, 'The role of perceived usability, reputation satisfaction and consumer familiarity on the website loyalty formation process', Computers in Human Behavior 24(2), 325-345. http://dx.doi.org/10.1016/j.chb. 2007.01.017

Chang, H.H. \& Chen, S.W., 2008, 'The impact of customer interface quality, satisfaction and switching costs on e-loyalty: Internet experience as a moderator', Computers in Human Behavior 24(6), 2927-2944. http://dx.doi.org/10.1016/j.chb.2008. 04.014

Chang, H.H. \& Chen, S.W., 2009, 'Consumer perception of interface quality, security, and loyalty in electronic commerce', Information \& Management 46(7), 411-417. http://dx.doi.org/10.1016/j.im.2009.08.002

Chen, S.-C., 2012, 'The customer satisfaction-loyalty relation in an interactive e-service setting: The mediators', Journal of Retailing and Consumer Services 19(2), 202-210. http://dx.doi.org/10.1016/j.jretconser.2012.01.001

Chen, Y.-C., Shang, R.-A. \& Kao, C.-Y., 2009, 'The effects of information overload on consumers' subjective state towards buying decision in the internet shopping environment', Electronic Commerce Research and Applications 8(1), 48-58. environment', Electronic Commerce Research
$\mathrm{http} / / / \mathrm{dx}$.doi.org/10.1016/j.elerap.2008.09.001

Chen, Y.-H., Hsu, I.C. \& Lin, C.-C., 2010, 'Website attributes that increase consumer purchase intention: A conjoint analysis', Journal of Business Research 63(9-10), 1007-1014. http://dx.doi.org/10.1016/j.jbusres.2009.01.023

Chien, S.-H., Chen, Y.-H. \& Hsu, C.-Y., 2012, 'Exploring the impact of trust and relational embeddedness in e-marketplaces: An empirical study in Taiwan', Industria Marketing Management 41(3), 460-468. http://dx.doi.org/10.1016/j.indmarman. 2011.05.001

Cyr, D., Hassanein, K., Head, M. \& Ivanov, A., 2007, 'The role of social presence in establishing loyalty in e-service environments', Interacting with Computers 19(1), 43-56. http://dx.doi.org/10.1016/j.intcom.2006.07.010

Dai, X. \& Grundy, J., 2007, 'NetPay: An off-line, decentralized micro-payment system for thin-client applications', Electronic Commerce Research and Applications 6(1) 91-101. http://dx.doi.org/10.1016/j.elerap.2005.10.009

Dubé, L., Cervellon, M.-C. \& Jingyuan, H., 2003, 'Should consumer attitudes be reduced to their affective and cognitive bases? Validation of a hierarchical model', International Journal of Research in Marketing 20(3), 259-272. http://dx.doi. org/10.1016/S0167-8116(03)00036-3

Følstad, A., Anda, B.C.D. \& Sjøberg, D.I.K., 2010, 'The usability inspection performance of work-domain experts: An empirical study', Interacting with Computers 22(2), 75-87. http://dx.doi.org/10.1016/j.intcom.2009.09.001

Gefen, D. \& Straub, D.W., 2004, 'Consumer trust in B2C e-commerce and the importance of social presence: experiments in e-products and e-services', Omega 32(6), 407-424. http://dx.doi.org/10.1016/j.omega.2004.01.006

Gummerus, J., Liljander, V., Pura, M. \& Riel, A., 2004, 'Customer loyalty to content based websites: the case of an online health-care service', Journal of Service Marketing 18(3), 175-186. http://dx.doi.org/10.1108/08876040410536486

Hair, J.F., Jr., Black, W.C., Babin, B.J. \& Anderson, R.E., 2010, Multivariate data analysis, Pearson Prentice Hall, New Jersey.

Hernández, B., Jiménez, J. \& Martín, M.J., 2010, 'Customer behavior in electronic commerce: The moderating effect of e-purchasing experience', Journal of Business Research 63(9-10), 964-971. http://dx.doi.org/10.1016/j.jbusres.2009.01.019

Hwang, Y., 2010, 'The moderating effects of gender on e-commerce systems adoption factors: An empirical investigation', Computers in Human Behavior 26(6), 1753-1760. http://dx.doi.org/10.1016/j.chb.2010.07.002

Iglesias-Pradas, S., Pascual-Miguel, F., Hernández-García, Á. \& Chaparro-Peláez, J., 2013, 'Barriers and drivers for non-shoppers in B2C e-commerce: A latent class exploratory analysis', Computers in Human Behavior 29(2), 314-322. http:// dx.doi.org/10.1016/j.chb.2012.01.024 
Keen, C., Wetzels, M., De Ruyter, K. \& Feinberg, R., 2004, 'E-tailers versus retailers: Which factors determine consumer preferences', Journal of Business Research 57(7), 685-695. http://dx.doi.org/10.1016/S0148-2963(02)00360-0

Kim, C., Galliers, R.D., Shin, N., Ryoo, J.-H. \& Kim, J., 2012, 'Factors influencing internet shopping value and customer repurchase intention', Electronic j.elerap.2012.04.002

Kim, C., Tao, W., Shin, N. \& Kim, K.-S., 2010, 'An empirical study of customers' perceptions of security and trust in e-payment systems', Electronic Commerce Research and Applications 9(1), 84-95. http://dx.doi.org/10.1016/j.elerap. 2009.04.014

Kim, D.J., Song, Y.I., Braynov, S.B. \& Rao, H.R., 2005, 'A multidimensional trust formation model in B-to-C e-commerce: a conceptual framework and content analyses of academia/practitioner perspectives', Decision Support Systems 40(2), 143-165. http://dx.doi.org/10.1016/j.dss.2004.01.006

Kim, J. \& Forsythe, S., 2008, 'Adoption of virtual try-on technology for online apparel shopping', Journal of Interactive Marketing 22(2), 45-59. http://dx.doi.org/ 10.1002/dir.20113

Kim, J., Jin, B. \& Swinney, J.L., 2009, 'The role of etail quality, e-satisfaction and e-trust in online loyalty development process', Journal of Retailing and Consumer Services 16(4), 239-247. http://dx.doi.org/10.1016/j.jretconser.2008.11.019

Kirs, P. \& Bagchi, K., 2012, 'The impact of trust and changes in trust: A national comparison of individual adoptions of information and communication technologies and related phenomenon', International Journal of Information Management 32(5), 431-441. http://dx.doi.org/10.1016/j.ijinfomgt.2012.02.003

Koh, Y.J. \& Sundar, S.S., 2010, 'Effects of specialization in computers, web sites, and web agents on e-commerce trust', International Journal of Human-Computer Studies 68(12), 899-912. http://dx.doi.org/10.1016/j.ijhcs.2010.08.002

Koo, D.-M., 2006, 'The fundamental reasons of e-consumers' loyalty to an online store', Electronic Commerce Research and Applications 5(2), 117-130. http://dx. doi.org/10.1016/j.elerap.2005.10.003

Kousaridas, A., Parissis, G. \& Apostolopoulos, T., 2008, 'An open financial services architecture based on the use of intelligent mobile devices', Electronic
Commerce Research and Applications 7(2), 232-246. http://dx.doi.org/10.1016/j. Commerce Research

Lai, J.Y., 2006, 'Assessment of employees' perceptions of service quality and satisfaction with e-business', International Journal of Human-Computer Studies 64(9), 926-938. http://dx.doi.org/10.1016/j.ijhcs.2006.04.007

Lin, C.-C., Wu, H.-Y. \& Chang, Y.-F., 2011, 'The critical factors impact on online custome satisfaction', Procedia Computer Science 3, 276-281. http://dx.doi.org/10.1016/j. procs.2010.12.047

Mazaheri, E., Richard, M.-O. \& Laroche, M., 2011, 'Online consumer behavior: Comparing Canadian and Chinese website visitors', Journal of Business Research 64(9), 958-965. http://dx.doi.org/10.1016/j.jbusres.2010.11.018

Min, S. \& Wolfinbarger, M., 2005, 'Market share, profit margin, and marketing efficiency of early movers, bricks and clicks, and specialists in e-commerce', Journal of Business Research 58(8), 1030-1039. http://dx.doi.org/10.1016/j. jbusres.2004.02.005

Muylle, S. \& Basu, A., 2004, 'Online support for commerce processes and survivability of web retailers', Decision Support Systems 38(1), 101-113. http://dx.doi.org/ of web retailers, Decision Support
$10.1016 /$ S0167-9236(03)00074-5
Overby, J.W. \& Lee, E.-J., 2006, 'The effects of utilitarian and hedonic online shopping value on consumer preference and intentions', Journal of Business Research 59(10/11), 1160-1166. http://dx.doi.org/10.1016/j.jbusres.2006.03.008

Palvia, P., 2009, 'The role of trust in e-commerce relational exchange: A unified model', Information \& Management 46(4), 213-220. http://dx.doi.org/10.1016/j. im.2009.02.003

Park, Y.J., Campbell, S.W. \& Kwak, N., 2012, 'Affect, cognition and reward: Predictors of privacy protection online', Computers in Human Behavior 28(3), 1019-1027. hrttp://dx.doi.org/10.1016/j.chb.2012.01.004

Qiu, L. \& Li, D., 2008, 'Applying TAM in B2C E-commerce research: An extended model', Tsinghua Science \& Technology 13(3), 265-272. http://dx.doi.org/ 10.1016/S1007-0214(08)70043-9

Quaddus, M. \& Achjari, D., 2005, 'A model for electronic commerce success', Telecommunications Policy 29(2/3), 127-152. http://dx.doi.org/10.1016/j.telpol. 2004.11.009

Safa, N.S., 2014, 'Modelling of multi-dimensional loyalty in electronic commerce'.

Safa, N.S., Ghani, N.A. \& Ismail, M.A., 2014, 'An artificial neural network classification approach for improving accuracy of customer identification in e-commerce', Malaysian Journal of Computer Science 27(3), 171-185.

Safa, N.S. \& Ismail, M.A., 2013, 'A customer loyalty formation model in electronic commerce', Doctoral thesis, University of Malaya, Economic Modelling 35, 559-564. http://dx.doi.org/10.1016/j.econmod.2013.08.011

Safa, N.S., Sookhak, M., Von Solms, R., Furnell, S., Ghani, N.A. \& Herawan, T., 2015, 'Information security conscious care behaviour formation in organizations', Computers \& Security 53, 65-78. http://dx.doi.org/10.1016/j.cose.2015.05.012

Salehi, F., Abdollahbeigi, B., Langroudi, A.C. \& Salehi, F., 2012, 'The impact of website information convenience on e-commerce success of companies', Procedia-Social and Behavioral Sciences 57, 381-387. http://dx.doi.org/10.1016/j.sbspro.2012. 09.1201

Shankar, V., Smith, A.K. \& Rangaswamy, A., 2003, 'Customer satisfaction and loyalty in online and offline environments', International Journal of Research in Marketing 20(2), 153-175. http://dx.doi.org/10.1016/S0167-8116(03)00016-8

Stefani, A. \& Xenos, M., 2011, 'Weight-modeling of B2C system quality', Computer Standards \& Interfaces 33(4), 411-421. http://dx.doi.org/10.1016/j.csi.2011.01.002

Tsai, H.-T. \& Huang, H.-C., 2007, 'Determinants of e-repurchase intentions: An integrative model of quadruple retention drivers', Information \& Management 44(3), 231-239. http://dx.doi.org/10.1016/j.im.2006.11.006

Van Schaik, P. \& Ling, J., 2008, 'Modelling user experience with web sites: Usability, hedonic value, beauty and goodness', Interacting with Computers 20(3), 419-432. http://dx.doi.org/10.1016/j.intcom.2008.03.001

Wang, H.-C., Pallister, J.G. \& Foxall, G.R., 2006, 'Innovativeness and involvement as determinants of website loyalty: II. Determinants of consumer loyalty in B2C e-commerce', Technovation 26(12), 1366-1373. http://dx.doi.org/10.1016/j. technovation.2005.11.003

Zuccato, A., 2007, 'Holistic security management framework applied in electronic commerce', Computers \& Security 26(3), 256-265. http://dx.doi.org/10.1016/j. cose.2006.11.003 